\title{
The Possible Antidiabetic Effect of Ficus carica L. Tablet on Iloxan-Induced Diabetes Model in Rats
}

\author{
Muhammad Fariez Kurniawan*, Fadhilah Alvari Yusuf \\ Department of Pharmacy Technology, School of Pharmacy, Faculty of Medicine and Health Sciences, Universitas Muhammadiyah \\ Yogyakarta, Indonesia
}

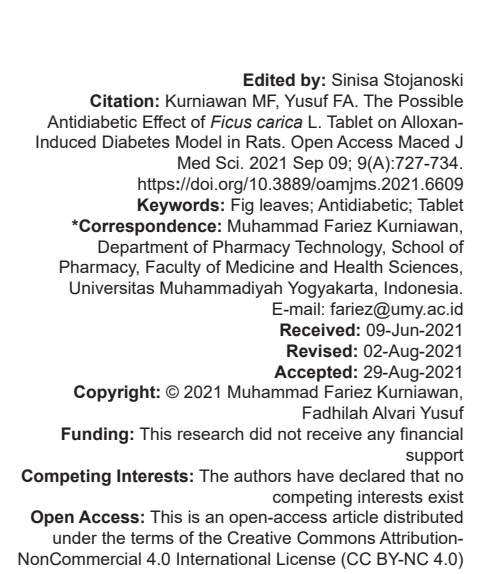

\section{Introduction}

Diabetes mellitus is a metabolic system disorder characterized by an increase in glucose levels in the blood. Diabetes mellitus occurs as glucose is built up in the blood and fails to enter the cells. The failure is caused by the hormone insulin not functioning properly, or the amount is insufficient. The function of the insulin hormone is to help glucose enter cells [1]. Annually, WHO predicts an increase in diabetes mellitus sufferers. In 2040, the number of people with diabetes mellitus in Indonesia was predicted to reach 642 million [2]. With the high number of diabetes sufferers and the expensive treatment of the disease, it is necessary to have alternative therapies in herbal treatments that show good effectiveness and safety [3]. Fig plants are included in the mulberry (Moraceae) plant group. Fig leaves are one of 400 plants reported to be used as an antidiabetic. In tropical and subtropical areas, fig leaves are widespread, and it is reported that they have effectiveness as antidiabetic, antimicrobial, antipyretic, anti-cancer, antibacterial, and anti-inflammatory [4]. Boiled water and stew of fig leave methanol extract are reported to treat diabetes.

Fig leaves with the Latin name Ficus carica L. contain flavonoid compounds, $\beta$-sitosterol, and polyphenols reported to have antidiabetic effects [5]. More flavonoid content will be obtained using ethanol as a solvent compared to other solvents [6]. Various dose 100,200 , and $400 \mathrm{mg} / \mathrm{kg}$ body weight of extract were administered orally to the rats shown has no adverse effect on the liver or blood constituents and possess no hepatotoxic activity. [7]. Ethanol extract at a dose of $200 \mathrm{mg} / \mathrm{kg}$ body weight can affect the decrease in blood sugar and cholesterol in alloxan-induced male white mice, better than the dose of 100 and $300 \mathrm{mg} /$ $\mathrm{kg}$ body weight and not significantly different compared to glibenclamide in reducing blood sugar levels of male white mice induced by alloxan [8]. Looking at the 
problems and potential of fig leaves, it is necessary to conduct a study where fig leaves need to be formed in a tablet formulation as an alternative to diabetes treatment and can increase the therapeutic effect. It has prompted researchers to conduct research on the effects of fig leaves as an antidiabetic developed in tablet dosage forms. The choice of the in vivo method in this study was because we would like to identify the effect of giving fig leaves ethanol extract tablets to reduce rats' glucose levels in this study. The choice of tablet preparations is because tablet preparations are widely circulated in the community and easy to consume. It is expected that this research will be beneficial for the broader community with fewer side effects than using synthetic drugs.

\section{Materials and Methods}

\section{Materials}

The tools used in this study were analytical balances (Mettler Toledo), glassware (Iwaki Pyrex), microscope (Olympus), rat cage (size $50 \mathrm{~cm} \times$ $30 \mathrm{~cm})$, rotary evaporator (Erweka), water bath (Memmerth), sieve mesh number 14 and 16, oven, tablet printing machine, Semi-Automatic Hardness Tester Th 3b Copley, Friability Tester FR 2000 Copley, Disintegration Tester Erweka ZT X20, Spectrophotometer (Jasco).

\section{Methods}

\section{Preparation and extraction of fig leaves}

The simplicia determination of fig (F. carica L.) leaves was carried out at the Biology Laboratory, Faculty of Pharmacy, Ahmad Dahlan University (UAD). Simplicia fig leaves $710 \mathrm{gr}$ were macerated using $70 \%$ ethanol with a 1part powder ratio dissolved with 10 parts solvent. The viscous extract obtained from the extraction process is calculated as the percent yield using the formula.

$$
\text { Yield value }=\frac{\text { Weight of viscous extract obtained }}{\text { Weight of simplicia powder }} \times 100 \%
$$

\section{Flavonoid compound test with thin layer} chromatography (TLC)

Test for flavonoids and quercetin compounds used the TLC method with a GF 254 silica gel stationary phase and a mobile phase of ethyl acetate: methanol:water ratio of $6.5 ; 2.85 ; 3$. Comparator standards used were a quercetin [9].

\section{Tablets formulation}

Tablets were prepared using the wet granulation method and the intraextra granular method in disintegrant use. Extracts of fig leaves, lactose, Sodium Starch Glycolate (SSG), and amprotab were mixed in a container until they turned homogeneous (mixture 1). Furthermore, PVP was prepared and then dissolved in boiling water little by little and mixed until it turned homogeneous. After the PVP dissolves, it was then added to mixture 1 gradually until the mixture 1 was wetted to form clenched granules. The granules were then sieved using a sieve number 14 (1410 microns) and then oven-dried at a temperature of $50 \square$. Granules had been oven re-sifted using a sieve number 16 (1190 microns). Before mixing with the external phase, the obtained granules were subjected to an evaluation test first. After the granule evaluation test was carried out, the granules were mixed with magnesium stearate, talc, and SSG until they were homogeneous. When the granules were homogeneous with all formulas, they were ready to be molded into tablets. The formulation of each tablet is mentioned in Table 1 [10].

Table 1: Tablet formulation

\begin{tabular}{|c|c|c|c|c|}
\hline & Placebo & $\mathrm{FI}$ & FII & FIII \\
\hline $\begin{array}{l}\text { Internal } \\
\text { phase (94\%) }\end{array}$ & $\begin{array}{l}\text { Lactose } \\
\text { monohidrat }\end{array}$ & $\begin{array}{l}40 \mathrm{mg} \\
\text { Extract of fig } \\
\text { leaves }\end{array}$ & $\begin{array}{l}60 \mathrm{mg} \\
\text { Extract of fig } \\
\text { leaves }\end{array}$ & $\begin{array}{l}80 \mathrm{mg} \\
\text { Extract of fig leaves }\end{array}$ \\
\hline & $\begin{array}{l}\text { Lactose } \\
\text { monohidrat } \\
\text { SSG 2\% } \\
\text { Amprotab 20\% } \\
\text { Aquadest } \\
\text { PVP 3\% }\end{array}$ & $\begin{array}{l}\text { Lactose } \\
\text { monohidrat } \\
\text { SSG 2\% } \\
\text { Amprotab 20\% } \\
\text { Aquadest } \\
\text { PVP 3\% }\end{array}$ & $\begin{array}{l}\text { Lactose } \\
\text { monohidrat } \\
\text { SSG 2\% } \\
\text { Amprotab 20\% } \\
\text { Aquadest } \\
\text { PVP 3\% }\end{array}$ & $\begin{array}{l}\text { Lactose monohidrat } \\
\text { SSG 2\% } \\
\text { Amprotab 20\% } \\
\text { Aquadest } \\
\text { PVP 3\% }\end{array}$ \\
\hline $\begin{array}{l}\text { External } \\
\text { phase (6\%) }\end{array}$ & $\begin{array}{l}\text { Talc } 1.5 \% \\
\text { Magnesium } \\
\text { stearate } 1.5 \% \\
\text { SSG } 3 \%\end{array}$ & $\begin{array}{l}\text { Talc } 1.5 \% \\
\text { Magnesium } \\
\text { stearate } 1.5 \% \\
\text { SSG } 3 \%\end{array}$ & $\begin{array}{l}\text { Talc } 1.5 \% \\
\text { Magnesium } \\
\text { stearate } 1.5 \% \\
\text { SSG } 3 \%\end{array}$ & $\begin{array}{l}\text { Talc } 1.5 \% \\
\text { Magnesium } \\
\text { stearate } 1.5 \% \\
\text { SSG } 3 \%\end{array}$ \\
\hline
\end{tabular}

\section{Granule evaluation}

\section{Physical examination}

The finished granules are seen in their shape and size. Good granules have a non-oval shape and are relatively the same size [11].

\section{Granule compressibility test}

Compressibility is the ability of granules to form tablets at a certain pressure. The finished granules are put in a special measuring cup to the stated volume. The greater the compressibility value of the granules, the less good the flow properties. The measurement used compressibility index with the equations:

Compressibility index : $\frac{\mathrm{V} 0-\mathrm{V} 1}{\mathrm{~V} 1} \times 100 \%$

V0: volume of granules before treatment

$\mathrm{V} 1$ : volume of granules after treatment 
Moisture content

Moisture content test was carried out using the moisture balance method, a method that applies thermogravimetric with very high accuracy. Moisture analyzers use infrared or halogen as a heat source that will evaporate water in granules [11].

\section{Tablet evaluation}

Physical examination

Physical examination of the tablet is done by observing the tablet directly in terms of color, surface shape of the tablet and other physical disabilities [11].

\section{Weight diversity test}

Weight uniformity test is done by weighing 20 tablets carefully and calculating the average weight of each dose variation. Then weigh one tablet at a time from each dose variation [11].

\section{Size uniformity test}

This test is carried out using a caliper. A total of 20 tablets were measured in diameter and thickness using calipers and look for averages. Tablet diameters range from $4 / 3$ to 3 times the thickness of the tablets [11].

\section{Tablet hardness test}

In the tablet hardness test, the Hardness Tester tool is used by as many as ten tablets placed on the test equipment one by one and the tool operated. The pressure results obtained are recorded from each tablet [11].

\section{Friability test/tablet friability}

In the tablet hardness test using a friability tool by 20 tablets was weighed and recorded by weight (W0). After that, 20 tablets were put into the device and operated for $4 \mathrm{~min}$ at a speed of $25 \mathrm{rpm}$ or equivalent to 100 revolutions. After that, all tablets are removed and cleaned from existing fines and weighed (W1) [11].

\section{Disintegration time test}

The disintegration time test is carried out with a Disintegrator Tester by means of six tablets put in each basket, one basket containing one tablet. Previously, aquadest have been put in test containers and special tubes for baskets that have been heated to $37^{\circ} \mathrm{C} \pm 2^{\circ} \mathrm{C}$. After the tablet is inserted, then the basket is put in each tube and the appliance is operated for $15 \mathrm{~min}$. After that, observe each tablet that is in each basket. If there are still one or two tablets that are not completely destroyed, then repeat the test [11].

\section{Tablet dissolution test}

In terms of the dissolution test, the standard curve was first determined. The standard curve determination for the dissolution test was carried out by dissolving the quercetin solution into ethanol with five different concentrations. This study used a concentration of 4 PPM, 8 PPM, 16 PPM, 20 PPM, and 24 PPM. The dissolved quercetin was then read for its absorbance using spectrophotometry with a wavelength of $435 \mathrm{~nm}$ [12]. After obtaining the absorbance of each concentration, the standard curve value was calculated. In this research, two dissolution tests were carried out: the S1 stage and the $\mathrm{S} 2$ stage because, at the $\mathrm{S} 1$ stage, the resulting dissolution test results did not meet the requirements. It was necessary to carry out the $\mathrm{S} 2$ dissolution test [11]. The dissolution test carried out in this study was a paddle dissolution test device with a speed of $50 \mathrm{rpm}$ at a temperature of $37^{\circ} \mathrm{C}$ for $45 \mathrm{~min}$, and every $5 \mathrm{~min}$, a $5 \mathrm{ml}$ solution was taken, which would later be analyzed by spectrophotometry with a wavelength of $435 \mathrm{~nm}$ [13]. In this research, the dissolution test passed the $\mathrm{S} 2$ stage.

\section{In vivo test on antidiabetic tablet effect}

This study was approved by the UMY Ethics Committee Number 051/EP-FKIK-UMY//II/2019. Rats used were 40 Wistar strains obtained from the Animal Laboratory of the Faculty of Medicine and Health Sciences, Universitas Muhammadiyah Yogyakarta. The rats used are male sex, because if using female can be influenced by more hormones than male rats. Before being treated, for 7 days the rats were adapted to the new environment and given standard feed and ad libitum water. There were eight groups of Wistar rats that included three control groups, namely, one normal group, one positive control group with metformin administration, and one negative group with alloxan without a cure. The other five groups were the sample groups given CMC induction treatment, placebo tablets, Formula I (FI) tablets, Formula II (FII) tablets, and Formula III (FIII) tablets with each dose containing $40 \mathrm{mg}, 60 \mathrm{mg}$, and $80 \mathrm{mg}$. In the previous study, a dose of $40 \mathrm{mg}$ was able to reduce oxidative stress parameters in streptozotocin induced rats [14]. Rats were acclimatized before being treated. All groups were given alloxan at a $150 \mathrm{mg} / \mathrm{kg}$ dose to make the rats develop diabetes except the normal group. Before being induced by alloxan, the rats were fasted for $12 \mathrm{~h}$ and only given distilled water. After the alloxan induction, the rats were left for 3 days to wait for an increase in their blood glucose levels and then their blood sugar levels were checked. Rats were considered to be diabetic when 
their blood sugar levels were above $140 \mathrm{mg} / \mathrm{dl}$. Normal blood sugar levels of rats were 50-135 mg/dl. Rats with diabetes were given antidiabetic tablets for 14 days and were monitored for glucose levels on days 9 and 14

Measurement of glucose levels in rats was carried out 4 times: First, before alloxan was induced to determine the initial value of glucose levels in rats, second on day 3 after alloxan induction to determine an increase in glucose levels in rats, and third and fourth were carried out respectively on the $9^{\text {th }}$ and $14^{\text {th }}$ day after being given therapy. The antidiabetic aimed to monitor the effects of the therapy that has been given. The calculation of serum blood glucose levels was determined by the GOD-PAP method. Blood was drawn from the retro orbital vein with a hematocrit pipette of $\pm 1 \mathrm{ml}$. The blood that had been drawn was collected first and allowed to clot to separate the serum from the blood cells. Centrifugation was performed at a speed of $2500 \mathrm{rpm}$ for $15-20 \mathrm{~min}$; thus, the serum could separate completely. The separated serum was stored at a temperature of $2-8 \square$ so that the serum was not damaged. Each solution was then mixed and let it sit for $10 \mathrm{~min}$ at $37 \square$ then the absorbance was read using a spectrophotometer with a wavelength of $500 \mathrm{~nm}$, and the glucose level was calculated using the formula of GOD-PAP method [15].

In vivo test of tablets' antidiabetic effect was carried out by inducing tablets into rats using a sonde. Before giving to the rats, the tablets were dissolved first using $0.6 \% \mathrm{CMC}$. The function of CMC $0.6 \%$ is to make tablet into suspension preparations. The preparation of the suspension is done by first developing the CMC by leaving it in distilled water for 1 day. After the CMC solution is formed, mix with a tablet and crush until homogeneous then taken $2.5 \mathrm{~mL}$ of the suspension. Previously, the rats were induced with alloxan $150 \mathrm{mg} /$ $\mathrm{kg}$ and waited for 3 days. The serum was then added with reagents, and the absorbance was read using spectrophotometry with a wavelength of $500 \mathrm{~nm}$. Then, the results obtained were analyzed using the one-way ANOVA test [16].

\section{Results}

The determination results showed that the plants obtained were in accordance with the main ingredients used in this study, namely, fig plants with fig species ( $F$. carica $L$ ) with the results are $1 b-2 b-3 b$ 4b-12b-13b-14b-17b-18b-19b-20b-21b-22b-23b-24b25b-800a-Moraceae 1a ficus-1b-16b-25b-40b-46a F. carica L. Maceration method was quite efficient as the yield obtained was quite good, amounting to $14.74 \%$. The compounds that were bottled were fig leaves extract (a), quercetin compound (b), rutin compound (c), tablet FI (d), tablet FII (e), and tablet FIII (f). Based on the data obtained, the length of all samples was equivalent to quercetin's length at both $254 \mathrm{~nm}$ and $366 \mathrm{~nm}$ wavelengths. Thin-layer chromatography test are shown in Figure 1.

\section{Granule evaluation}

The water content of the granule was the water content in the granule. Placebo tablets contained $3.4 \%$ water content, FI tablets contained $3.53 \%$ water content, FII tablets contained $3.87 \%$ water content, and FIII tablets contained $3.89 \%$ water content. Based on the data obtained, all granule had met the moisture content test requirements, namely, below $10 \%$ for natural extract granule [10]. The moisture content would affect the process of pressing the tablet, tablet hardness, and tablet brittleness. The high-water content would cause the granule to be difficult to compress and less hard. Meanwhile, the small water content made the tablets easily brittle [17].

\section{Compressibility test}

Compressibility granule was the ability of the granule to flow when it would be printed into tablets. The greater the granules' compressibility value was, the less the granules' flow properties would be. Placebo tablets had a compressibility value of $12 \%$; tablet FI had a compressibility value of $12 \%$; tablet FII had a compressibility value of $8 \%$, and tablet FIII had a compressibility value of $12 \%$. Based on the data obtained, the placebo, FI and FIII granule composability values were classified as good because they had a granule compressibility value of $12 \%$ [18]. Meanwhile, the compressibility of granule FII was very good. It can be seen from the compressibility percentage of granule FIl was below $10 \%$.

\section{Flow properties test}

Flow properties are the ability of the granule to flow when it was printed. Flow properties can be determined by measuring the flowing time and angle of repose. The placebo tablet had a flow rate of $5 \mathrm{~s}$; the FI tablet had a flow rate of 5.27; the FII tablet had a flow rate of 4.21; and the FIII tablet had a flow rate of 5.32. Based on the results of the data obtained, the granules' flow ability was classified as very good. It can be seen from the granule flow rate, which was below $10 \mathrm{~s}$ [19].

\section{Evaluation of tablets}

Physical Observation of Tablets: There were placebo tablets in this study, and three doses of fig leave ethanol extract used to make tablets, namely, $40 \mathrm{mg}, 60 \mathrm{mg}$, and $80 \mathrm{mg}$. Each tablet had different characteristics. The tablet with higher dose of fig leaves 
extract has be more smelled. The color of the tablets obtained from this formulation was green containing extracts. As for the placebo tablets, they were white.

\section{Weight uniformity}

Weight uniformity was evaluated by randomly weighing 20 tablets. The data obtained were calculated by calculating the average tablet weight divided by each tablet weight, and an absolute value was created and multiplied by $100 \%$. Each formula's results should not have 2 tablets deviating more than $5 \%$ and no one tablet that deviated more than $10 \%$ [11]. The weight of the tablet desired in this study was $600 \mathrm{mg}$. The data obtained showed that the evaluation of weight uniformity in the four tablet formulas revealed very good results. The results are FI $(617.8 \pm 3.25 \% \mathrm{mg})$, FII $(629.35 \pm 1.25 \% \mathrm{mg})$, FIII $(643.6 \pm 3.16 \% \mathrm{mg})$, and placebo tablet $(666.45 \pm 1.31 \% \mathrm{mg})$. It can be seen in the data obtained that no more than two tablets deviated more than $5 \%$, and no one tablet deviated more than $10 \%$. The uniformity of tablet weight was influenced by the granules' flow properties and the granules' compressibility [20].

\section{Tablet hardness}

Tablet hardness test was carried out to assess tablets' resistance to shock pressure during and after tablets' manufacture. Tablet hardness was evaluated using a hardness tester as many as 10 tablets [11]. Tablet hardness significantly affected the brittleness of a tablet. The greater the hardness of the tablet was, the smaller the brittleness would be. The hardness of the tablet was greatly influenced by the level of pressure when printing the tablet. In other words, the higher the pressure was used, the harder the resulting tablet would be. The hardness values of FI $(5.7 \mathrm{~kg}), \mathrm{FIl}(1.31 \mathrm{~kg})$, and FIII $(3.09 \mathrm{~kg})$, placebo tablet $(2.98 \%)$. Regarding the Placebo's hardness level, FII and FIII tablets did not meet the data's requirements. It could be seen in the data obtained showing that the three tablets had an average that did not enter the standard of tablet hardness, namely 4-8 kg [21]. While tablet FI had good hardness, it could be seen from the average hardness of tablet that FI was 5.7 included in the standard of tablet hardness.

\section{Friability of tablets}

The purpose of the tablet friability test was to determine tablets' resistance to shocks during the manufacturing, packaging, and distribution processes of tablets [11]. The requirement for the friability value of the tablet was $<1 \%$. The value of friability $\mathrm{FI}(1.42 \%)$, FII $(11.8 \%)$, and FIII $(0.84 \%)$, placebo tablet $(1.16 \%)$. FI Based on the data obtained, $t$ showed that the tablet friability value of each formula was different. The value of tablet friability was inversely proportional to the value of tablet hardness. The lower the tablet hardness value was, the higher the tablet friability value would be. It was because the tablet was getting stronger. The bond between particles would be stronger, so the tablet would not be easily brittle [22]. The tablets' brittleness was influenced by the tablets' hardness, the binder's concentration, and the concentration of disintegrant used. The lower the binder concentration was, the more brittle the tablet would be, and the lower the disintegrant concentration was, the less brittle the tablet would be. Thus, the tablets' friability was directly proportional to the binder's concentration and inversely proportional to the disintegrant concentration. In the data obtained, only FII tablets had good friability values. The value of the friability of the FII tablet had a friability value of below $1 \%$. Meanwhile, in terms of the value of placebo, $\mathrm{FI}$ and FIII tablets had a friability value above $1 \%$.

\section{Disintegration time}

Disintegration time is the time taken for the tablet to break down into particles. The factor that affected the disintegration time of tablet preparations was the pressure exerted when printing the tablets [11]. Tablets that were put under more pressure had a longer disintegration time because the tablet's hardness would inhibit the penetration of liquid into the tablet's pores. In addition, the concentration of the binder significantly affected the disintegration time. Too much binder or too little disintegrants would result in longer tablet breakdown times because the bonds between particles were too strong, so it took a longer time to dissolve [22]. The requirement for the disintegration of natural ingredients tablets was $30 \mathrm{~min}$. Table placebo had a disintegration time value of 12:23 min; tablet $\mathrm{FI}$ had a disintegration time value of 11:02 min; tablet FII had a disintegration time value of $10: 10 \mathrm{~min}$; and tablet FIII had a disintegration time value of 17:00 min. Based on the data obtained, all tablets had a disintegration time that met the requirements, which was under $30 \mathrm{~min}$ because it used quite a lot of disintegrants excipients for the internal phase, namely, amprotab $20 \%$ and SSG $2 \%$ and, for the external phase, it used SSG 1.5\% [10].

\section{Dissolution}

In this study, two dissolution tests were carried out, namely, the S1 stage and the S2 stage. This is because at the $\mathrm{S} 1$ stage the results of the dissolution test that does not meet the requirements, it is necessary to carry out an S2 dissolution test. The dissolution test was carried out in this study using a paddle dissolution test apparatus at a speed of $50 \mathrm{rpm}$ at $37^{\circ} \mathrm{C}$ for $45 \mathrm{~min}$ and every $5 \mathrm{~min}$ a $5 \mathrm{ml}$ solution was taken which would later be analyzed by spectrophotometry with a wavelength of $435 \mathrm{~nm}$ [13]. In this study, the dissolution test passed the $\mathrm{S} 2$ stage. The table of tablet absorbance test results is described in Table 2. 
Table 2: Dissolution test

\begin{tabular}{llllll}
\hline Tablet & Stage & $\mathrm{Q}$ & $\mathrm{Q}+5 \%$ & $\mathrm{Q} 12$ tablet & $\mathrm{Q}-15$ \\
\hline F1 & S1 & 70.22 & 73.73 & 65.67 & - \\
& S2 & 61.12 & - & & 51.95 \\
F2 & S1 & 71.24 & 74.80 & 68.55 & - \\
& S2 & 65.87 & - & & 55.99 \\
F3 & S1 & 66.48 & 69.80 & 66.39 & - \\
& S2 & 66.30 & - & & 56.36 \\
\hline
\end{tabular}

\section{In vivo test on antidiabetic tablet effect}

Rats with diabetes were given antidiabetic tablets for 14 days and glucose levels were monitored on days 9 and 14. Antidiabetic tablets used orally were metformin at a dose of $150 \mathrm{mg} / \mathrm{kg}$ body weight, ethanol extract tablets at a dose of $20 \mathrm{mg}, 40 \mathrm{mg}$, and $60 \mathrm{mg}$ and placebo tablets.

Measurement of rats glucose levels was carried out 4 times. First, before alloxan was induced to determine the initial value of glucose levels in rats, secondly on the 3rd day after alloxan induction to determine an increase in glucose levels in rats after alloxan was induced, the third and fourth were carried out respectively on the 9th and 14th days after being given therapy antidiabetic in order to monitor the effect of the therapy that has been given.

\section{Discussion}

The ethanol extract tablet formulation of fig leaves was carried out by wet granulation method. The first step is the phase weighing process in the formula. After the weighing process, the process of making the internal phase is carried out by mixing the ingredients in the form of ethanol extract of fig leaves, lactose, $2 \%$ SSG, and $20 \%$ amprotab until homogeneous (mixture 1) then carried out the dissolving process of PVP $3 \%$ into water at a temperature of $80^{\circ} \mathrm{C}$. The process of dissolving PVP with water at a temperature of $80^{\circ} \mathrm{C}$ aims to dissolve PVP and also to prevent PVP from blowing faster than using $70 \%$ ethanol solvent. After PVP dissolves in air, then mix it with mixture 1 that was made previously. The mixing of PVP with mixture 1 aims to form bonds between particles so that they can be formed into granules [23].

After all the formulas have been mixed and homogeneous, the sieve is done with a mesh number 12 sieve. The purpose of sieving is to form the powder into granules and to accelerate the drying process. The wet granules that have been formed are then dried using an oven at a temperature of $50^{\circ} \mathrm{C}$. Drying the granules aims to evaporate the water in the granules to obtain dry granules, so that it can facilitate the process of pressing the tablets. After obtaining the dry granule, the granule was then subjected to a second sieve with a mesh sieve number 16 . This sieving aims
Table 3: Rats' blood glucose level (mg/dl)

\begin{tabular}{llllll}
\hline Group & \multicolumn{6}{l}{ Blood glucose level $(\mathrm{mg} / \mathrm{dl})$} \\
\cline { 2 - 6 } & Initials & 9 days & 14 days & Change in levels & $\%$ Change in levels \\
\hline Normal & $51 \pm 4$ & $61 \pm 5$ & $67 \pm 4$ & 16 & $31.1 \%$ \\
Negative & $460 \pm 35$ & $520 \pm 33$ & $547 \pm 33$ & 87 & $18.9 \%$ \\
Positive & $554 \pm 47$ & $390 \pm 46$ & $327 \pm 46$ & -227 & $-40.9 \%$ \\
Placebo & $452 \pm 56$ & $502 \pm 53$ & $538 \pm 54$ & 86 & $19 \%$ \\
Base & $383 \pm 78$ & $431 \pm 79$ & $468 \pm 79$ & 85 & $22.1 \%$ \\
FI & $535 \pm 20$ & $383 \pm 20$ & $350 \pm 20$ & -173 & $-32.3 \%$ \\
FII & $538 \pm 15$ & $354 \pm 15$ & $280 \pm 15$ & -258 & $47.9 \%$ \\
FIII & $553 \pm 24$ & $353 \pm 24$ & $266 \pm 24$ & -287 & $51.8 \%$ \\
\hline FI: Formula I, FII: Formula II, FIII: Formula III.
\end{tabular}

to facilitate the process of pressing the tablets. The dried granules were then added with an external phase, namely SSG $3 \%$, Mg Stearate $1.5 \%$ and Talc $1.5 \%$. This mixing process aims to improve the smoothness of the granules when poured into the hoper, facilitate the tablet molding process and also increase the tablet disintegration time. After the external phase is added, tablet printing is carried out. The active substance used in this study was the ethanol extract of fig leaves with three different doses which were used as antidiabetic therapy in rats. Apart from the active substances, there are excipients that must be used in the manufacture of wet granulation method tablets, namely, fillers, disintegrants, binders, lubricants, and glidants. Fillers are used to give weight to the tablets and the one used in this study is lactose monohydrate. The disintegrants was used to increase the solubility of the tablets while in the stomach and in this study the disintegrants used were $2 \%$ SSG and $20 \%$ amprotab. The SSG used in this study was used in the internal and external phases, this is because the quercetin as active substances contained in fig leaves extract have a long disintegration time Quercetin being a flavonol belonging to Class II of BCS (Biopharmaceutical Classification) [24]. SSG is a super-disintegrant material which functions to increase the dissolution rate of drugs [25].

In the wet granulation method, an external phase is required in the form of glidants, lubricants and disintegrants. The glidan used in this study was talc $1.5 \%$. Talc serves to increase the fluidity of the mass to be compressed by reducing friction between particles. Meanwhile, the lubricant used in this study was $\mathrm{Mg}$ stearate $1.5 \%$. Mg stearate functions to reduce friction between the surface of the powder particles and the die walls during compression and ejection. In this research, disintegrants is used as an external phase; this is because the active substance has a low disintegration time [26]. Tablet are shown in Figure 2.

In the normal group, rats were not induced by alloxan, so that their glucose levels were not as high as those induced by alloxan. The purpose of holding the normal group was to determine the rats' normal condition for 14 days. The normal group experienced a change where it had an average blood level of $51 \pm$ $4 \mathrm{mg} / \mathrm{dl}$ at the beginning of the study. After the $9^{\text {th }}$ day, it became $61 \pm 5 \mathrm{mg} / \mathrm{dl}$, and on the $14^{\text {th }}$ day, it became $67 \pm 4 \mathrm{mg} / \mathrm{dl}$. This is because the food given to the rats is A.D.II which contains $15 \%$ protein so that it slightly affects the glucose content in the rat's blood. 


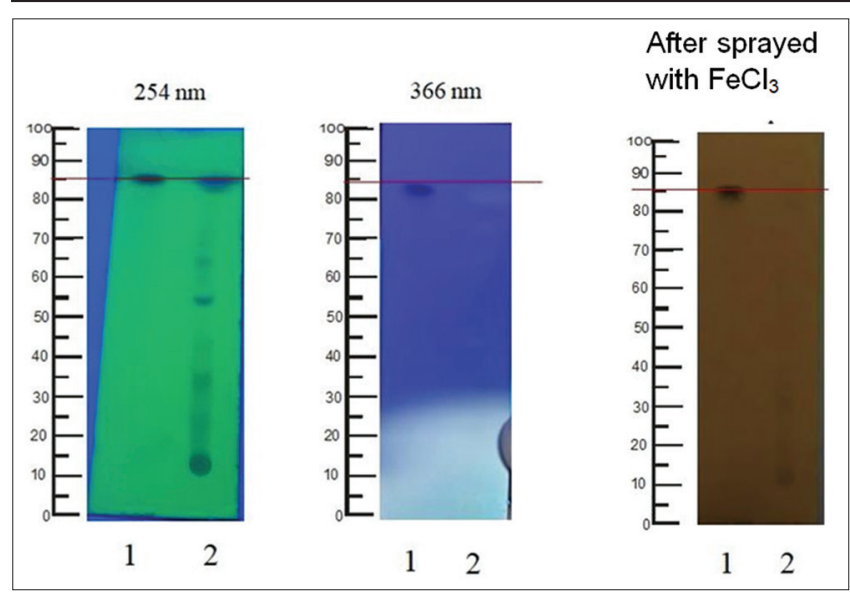

Figure 1: Thin-layer chromatography test with (a) standard compound quercetin, (b) ethanol extract of fig leaves

In the negative group, the rats still had diabetes from the beginning of the experiment to the end as they had been given alloxan before the initial blood draw. The negative group experienced a change where it had an average glucose level of $460 \pm 35 \mathrm{mg} / \mathrm{dl}$ at the beginning of the study. After the $9^{\text {th }}$ day, it became $520 \pm$ $33 \mathrm{mg} / \mathrm{dl}$, and on the $14^{\text {th }}$ day, it became $547 \pm 33 \mathrm{mg} / \mathrm{dl}$. The increase in sugar levels occurred as the pancreas' function was not normal due to the induction of alloxan, which damaged the pancreas' beta cells so that insulin production was not normal, which caused an abnormal increase in glucose [27]. Results are shown in table 3.

In the positive group, the rats had diabetes at the beginning of the blood draw because alloxan was given before the initial blood draw. The purpose of holding the positive group was to determine the

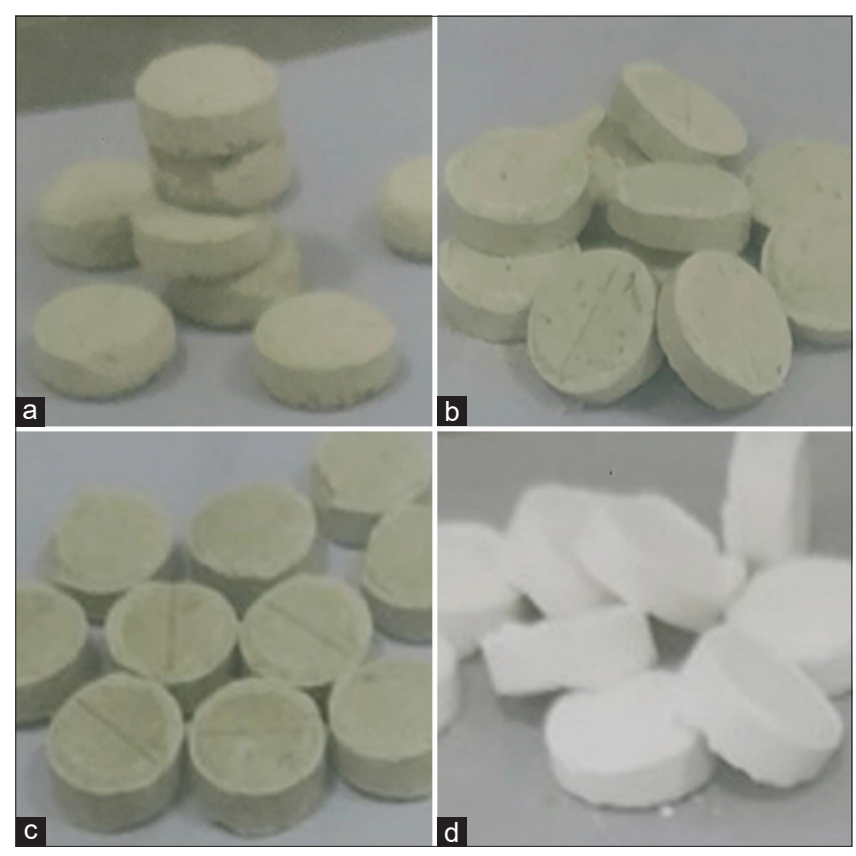

Figure 2: Tablet FI (a), Tablet FII (b), Tablet FIII (c), and Tablet Placebo (d). Fl contains $40 \mathrm{mg}$ of fig leaves extract, Fll contains 60 $\mathrm{mg}$ of fig leaves extract, FIII contains $80 \mathrm{mg}$ of fig leaves extract. Fl: Formula I, FII: Formula II, FIII: Formula III effect of metformin for 14 days. The positive group experienced a change where it had an average glucose level of $554 \pm 47 \mathrm{mg} / \mathrm{dl}$. After the $9^{\text {th }}$ day, it became $390 \pm 46 \mathrm{mg} / \mathrm{dl}$, and on the $14^{\text {th }}$ day, it became $327 \pm$ $46 \mathrm{mg} / \mathrm{dl}$. Metformin worked to reduce glucose levels by stimulating insulin secretion [28]. The placebo group experienced a change where it had a mean glucose level of $452 \pm 56 \mathrm{mg} / \mathrm{dl}$ at the beginning of the study. After the $9^{\text {th }}$ day, $\mathrm{t}$ became $502 \pm 53 \mathrm{mg} / \mathrm{dl}$, and on the $14^{\text {th }}$ day, it became $508 \pm 54 \mathrm{mg} / \mathrm{dl}$. Placebo tablets did not contain compounds that could lower glucose levels, so placebo tablets could not reduce glucose levels.

In the base group, the rats had diabetes at the beginning of the blood draw because alloxan was given before the initial blood draw. The aim of holding the base group was to determine CMC Na's effect when inducing tablets into rats for 14 days. The base group experienced a change, where at the beginning of the study, it had an average glucose level of $383 \pm 78 \mathrm{mg} / \mathrm{dl}$. After the $9^{\text {th }}$ day, it became $431 \pm 79 \mathrm{mg} / \mathrm{dl}$, and on the $14^{\text {th }}$ day, it became $438 \pm 79 \mathrm{mg} / \mathrm{dl}$. In $\mathrm{CMC} \mathrm{Na}$, which was used to make a suspension when induced to rats, it did not contain compounds that could reduce glucose levels. The highest ability to reduce glucose levels was tablet FIII compared to tablets $\mathrm{FI}$ and FII, which were significantly different because the FIII tablets contained more quercetin compounds than the FI and FII tablets. Whereas FII tablets had less quercetin compound compared to FIII and more than $\mathrm{FI}$, so the ability of FII tablets to reduce glucose levels was not as good as FIII. Tablet FI had the lowest quercetin compound so that the ability to reduce glucose levels was lower than that of FII and FIII tablets and was significantly different that could be seen in the value ( $p<0.05)$. Quercetin could reduce blood glucose levels by keeping pancreatic $\beta$ cells working normally [29]. Treatment of quercetin has also shown to have ameliorative effects on type 2 diabetes in both in vitro and in vivo studies. Quercetin has been shown to effectively lower the plasma glucose levels and improve other diabetic-related parameters. The decreased levels of serum insulin in diabetic rats caused by the destruction of pancreatic $\beta$-cells were restored by quercetin treatments [30]. However, the actual mechanisms of these compounds are not fully understood.

\section{Conclusion}

The tablet formulation obtained to make ethanol extract tablets was to use the internal phase in the form of SSG $2 \%$ as a disintegrant, Amprotab $20 \%$ as a filler and disintegrant, PVP $3 \%$ as a binder with water solvent and filler in the form of lactose monohydrate and with an external phase in the form of talc $1.5 \%$ as a glidant, $\mathrm{Mg}$ stearate $1.5 \%$ as lubricant and SSG $3 \%$ as disintegrant. The ethanol extract of fig leaves had a significant effect 
on reducing blood glucose levels of alloxan-induced rats. It could be seen from comparing the decrease in blood glucose levels in the FI, FII, and FIII groups compared with negative controls. The dose of fig leaves ethanol extract tablet had a significant effect at $80 \mathrm{mg} /$ tablet. It could be seen from the comparison of changes in glucose levels in the FIII group with positive control. The $\mathrm{FI}$ and FII groups used the one-way ANOVA test with a value $(p<0.05)$. The dose of fig leaves ethanol extract tablets in FII and FIII groups had a higher effect than positive controls, which differed significantly. It could be seen from the comparison of the decrease in glucose levels in positive control with FII and FIII groups using the one-way ANOVA test with a value $(p<0.05)$.

\section{References}

1. World Health Organization. Global Report on Diabetes. France: World Health Organization; 2016.

2. International Diabetes Federation. IDF Diabetes Atlas. $7^{\text {th }}$ ed. Brussels, Belgium: International Diabetes Federation; 2015.

3. Park S, Park JS, Go H, Jang BH, Shin Y, Ko SG. The efficacy and safety study of dietary supplement PURIAM110 on noninsulin taking Korean adults in the stage of pre-diabetes and diabetes mellitus: Protocol for a randomized, double-blind, CMC Na-controlled, and multicenter trial-pilot study. Trials. 2011;12:38, 1-7. https://doi.org/10.1186/1745-6215-12-38

4. Ahaddin AY. Isolasi dan Sitotoksisitas Ektrak Flavonoid daun Tin (Ficus carica L). Bogor: IPB; 2014.

5. Khan KY, Khan MA, Ahmad M, Hussain I, Mazari P, Fazal H, et al. Hypoglycemic potential of genus Ficus L.: A review of ten years of plant based medicine used to cure diabetes (20002010). J Appl Pharm Sci. 2011;1:223-7.

6. Trifunschi SI. dan Ardelean DG. Flavonoid extraction from Ficus carica $\mathrm{L}$ leaves using different techniques and solvent. J Nat Sci. 2013;125:79-84. https://doi.org/10.2298/zmspn1325081t

7. Odo GE, Agwu JE, Newze N, Nwadinigwa A, Onyeke CC, Nzekwe $\mathrm{U}$, et al. Toxicity and effects of fig (Ficus carica) leaf aqueous extract on haematology and some biochemical indices of wistar albino rats (Rattus norvegicus). J Med Plants Res. 2016;10(22):298-305.

8. Wijaya ZA. Antidiabetes Ekstrak Etanol Daun Tin (Ficus carica L.) pada Mencit (Mus Musculus) yang Diinduksi Aloksan. Prosiding Seminar Nasional Kesehatan, Jilid I, hlm; 2010. p. 1-9. https://doi.org/10.29313/jiff.v2i1.4059

9. Kurniawan MF, Irawan MI, Prakoso A, Sugihartini N. Antiinflammatory activity effect of Ficus carica and Ziziphus mauritiana leaves. Int J Pharm Res. 2020;12(1):920-7.

10. Niazi S. Handbook of Pharmaceutical Manufacturing Formulations Compressed Solid Products. $2^{\text {nd }}$ ed., Vol. 1. Informa Healthcare; 2009. p. 67-9, 73-4.

11. Departemen Kesehatan. Farmakope Indonesia. $5^{\text {th }}$ ed. Jakarta: Departemen Kesehatan Republik Indonesia; 2014. https://doi. org/10.6066/jtip.2013.24.2.121

12. Serra DR, Chang CH, K.H., Dezani, T.M., Porta, Valentina., Sílvia, Storpirtis. Dissolution efficiency and bioequivalence study using urine data from healthy volunteers: A comparison between two tablet formulations of cephalexin. Braz J Pharm Sci. 2015;5(2):16. https://doi.org/10.1590/s1984-82502015000200016

13. Stankovic MS. Total phenolic content, flavanoid concentrations and antioxidant activity, of the whole plant and plant parts extract from Teucrium montanum L. Var. montanum, F. supinum (L.) Reichenb Biotechnol Biotechnol Eq. 2011;25(1):2222-7. https:// doi.org/10.5504/bbeq.2011.0020

14. Pèrez $C$, Canal J, Torres $M$. Experimental diabetes treated with Ficus carica extract: Effect on oxidative stress parameters. Acta Diabetol. 2003;40(1):3-8. https://doi.org/10.1007/s005920300001 PMid: 12682822

15. Baroroh F, Aznam N, Susanti H. Uji Efek Antihiperglikemik Ekstrak Etanol Daun Kacapiring (Gardenia augusta, Merr) Pada Tikus Putih Jantan Galur Wistar. Pharmaciana. 2011;1(1):515. https://doi.org/10.12928/pharmaciana.v1i1.515

16. Wilda. Perbandingan Variasi Suhu Pengeringan Granu Terhadap Kadar Air Dan Sifat Fisis Tablet Paracetamol. Surakarta: Penerbit UNS; 2012.

17. Anonim. The stationary office on behalf of medicine and healthcare products regulatory agency (MHRA), England. $\mathrm{Br}$ Pharm. 2007;4:405-6.

18. Lachman L, Lieberman HA, Kanig JL. Teori dan Praktek Farmasi Industri II (Ed ke-3). Jakarta: UI-Press; 2008.

19. Hadisoewignyo L, dan Fudholi A. Sediaan Solida. Yogyakarta: Pustaka Pelajar; 2013.

20. Anonim. Peraturan Kepala Badan Pengawas Obat dan Makanan Republik Indonesia: Persyaratan Mutu Obat Tradisional. Indonesia: Badan Pengawas Obat dan Makanan Republik Indonesia; 2014. https://doi.org/10.30596/dll.v5i2.3577

21. Chowdary YA, Soumya M, Madhu BM, Aparna K, Himabindu P. A review on fast dissolving drug delivery systems a pioneering drug delivery technology. Bull Environ Pharmacol Life Sci. 2012;1:8-20.

22. Widya CA, Agus S, Dwi H. Pengaruh gelatin, amilum dan PVP sebagai bahan pengikat terhadap sifat fisik tablet ekstrak temulawak (Curcuma xanthorriza, Rzob). Pharmacy. 2010;7(2):58-66. https://doi.org/10.52943/jifarmasi.v4i2.518

23. Agoes G. Teknologi Bahan Alam. Bandung: Penerbit ITB; 2007.

24. Madaan K, Lather V, Pandita D. Evaluation of polyamidoamine dendrimers as potential carriers for quercetin, a versatile flavonoid. Drug Deliv. 2016;23(1):254-62. https://doi.org/10.31 09/10717544.2014.910564 PMid:24845475

25. Sharma D. Formulation development and evaluation of fast disintegrating tablets of salbutamol sulphate for respiratory disorders. ISRN Pharm. 2013;2013:674507. https://doi. org/10.1155/2013/674507

PMid:23956881

26. Elisya $Y$, Murtini G. Effect of soursop leaf extract tablets (Annona muricata L) against cancer cells. Asian J Appl Sci. 2015;3:244-8.

27. Ewenighi C, Uchechukwu D, Joel O, Linus O, Gladys $O$, Uchechukwu E. Estimation of glucoselevel and body weight in alloxan induced diabetic rat treated with aqueous extract of garcinia kola seed. Ulutas Med J. 2015;1(2):26-30. https://doi. org/10.5455/umj.20150507042420

28. Kennedy MS. Pancreatic drugs and antidiabetic drugs. In: Katzung BG, editor. Farmakologi Dasar dan Klinik. $12^{\text {th }}$ ed. Jakarta: EGC; 2012.

29. Mawa S, Husain K, dan Jantan I. Ficus carica L. (Moraceae): Phytochemistry, traditional uses and biological activities. Evid Based Complement Altern Med. 2013;2013:974256. https://doi. org/10.1155/2013/974256 PMid:24159359

30. Dong KY, Hyung SK. Anti-diabetic effect of cotreatment with quercetin and resveratrol in streptozotocin-induced diabetic rats. Biomol Ther. 2018;26(2):130-8. https://doi.org/10.4062/ biomolther.2017.254

PMid:29462848 